\title{
Peripherally inserted central catheter (PICC) placement: beware of the bends
}

\author{
Aditya Badheka, Kristen Brown, Veerajalandhar Allareddy
}

Department of Pediatrics, Stead Family Children's Hospital, University of lowa, lowa City, lowa, USA

\section{Correspondence to} Dr Aditya Badheka, aditya-badheka@uiowa.edu

Accepted 6 April 2018

\section{DESCRIPTION}

The peripherally inserted central catheter (PICC) is used as a long-term vascular access to deliver medications and venous nutrition. The PICC tip terminates close to the heart or in one of the great vessels-the superior vena cava or the inferior vena cava. Catheter tip confirmation is usually achieved by plain radiography. We describe a case of a 9-month-old boy with complex congenital heart disease (heterotaxy syndrome, polysplenia type) who underwent pulmonary artery banding to reduce pulmonary blood flow to control heart failure symptoms. PICC was placed in the left femoral vein during the postoperative period. PICC tip confirmation was obtained by anteroposterior plain abdominal radiograph (figure 1), which demonstrated catheter tip bending at T12. The lateral radiograph of the abdomen showed that the PICC courses posteriorly into the lumbar venous plexus (figure 2). The ascending lumbar veins arises at L5-S1 from the common iliac vein and drains into the epidural venous plexus. Inadvertent placement of the PICC in the lumbar veins may lead to a multitude of complications, including perforation of the venous system leading to extravasation of fluids into the spinal canal, ${ }^{1}$ air in the spinal canal leading to temporary paraplegia, ${ }^{2}$ and permanent neurological damage in the form of neurogenic bladder or flaccid paraplegia. ${ }^{3}$ The presentation of aberrant PICC placement varied and can be delayed

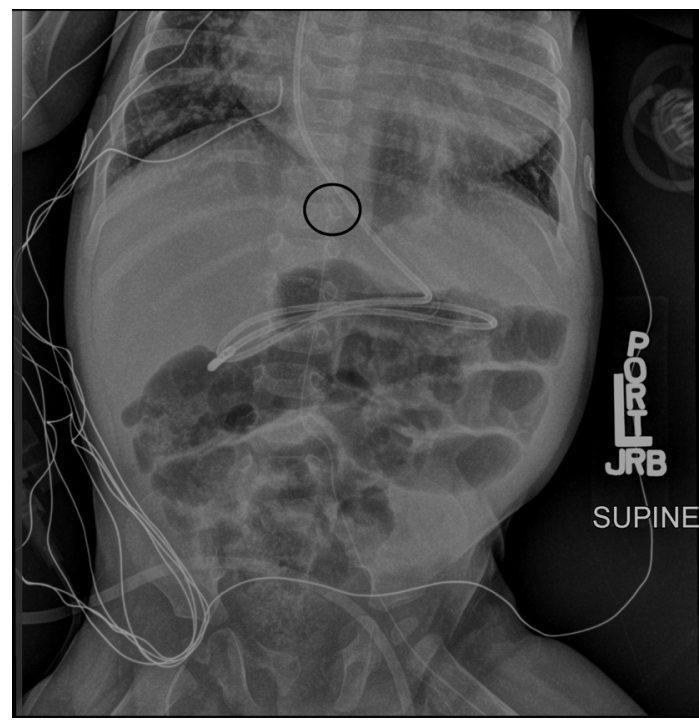

To cite: Badheka A, Brown Allareddy V. BMJ Case Rep Published Online First: [please include Day Month Year]. doi:10.1136/bcr-2018224688
Figure 1 Abdominal X-ray anteroposterior view. The left femoral vein peripherally inserted catheter appears to be in central circulation. The black circle shows the catheter tip bending at the level of T12.

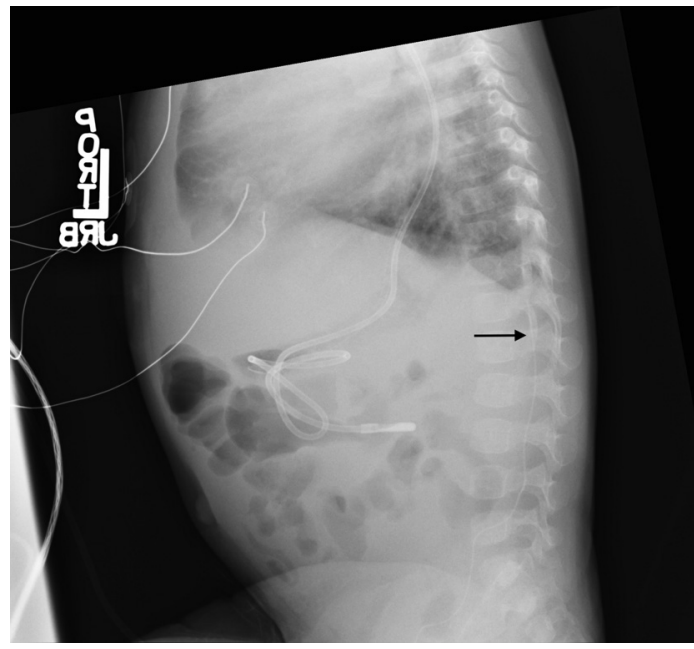

Figure 2 Abdominal X-ray lateral view. The black arrow shows the peripherally inserted central catheter courses posteriorly into the lumbar venous plexus and terminates at the level of T12.

Learning points

- Peripherally inserted central catheter (PICC) tip confirmation is usually achieved by plain radiography.

- The presentation of aberrant PICC placement is varied and diagnosis can be delayed by several days.

- The inadvertent PICC placement in the lumbar veins may result in temporary (fluid/air in spinal canal) or permanent complications (neurogenic bladder or flaccid paraplegia).

- The lateral plain abdominal radiograph may be considered for additional confirmation when the PICC tip lies in the inferior vena cava but does not advance to T8-T10, or takes an unexpected course (bends, curls).

for several days. ${ }^{2}$ The lateral plain abdominal radiograph may be considered for additional confirmation when the PICC tip lies in the inferior vena cava but does not advance to T8-T10, or takes an unexpected course (bends, curls).

Contributors $A B$ : literature search, figures, data collection, analysis, data interpretation, writing. KB: figures, data collection, analysis, data interpretation. VA: data collection, analysis, data interpretation, writing.

Funding The authors have not declared a specific grant for this research from any funding agency in the public, commercial or not-for-profit sectors. 


\section{Images in...}

Competing interests None declared.

Patient consent Parental/guardian consent obtained.

Provenance and peer review Not commissioned; externally peer reviewed.

(C) BMJ Publishing Group Ltd (unless otherwise stated in the text of the article) 2018. All rights reserved. No commercial use is permitted unless otherwise expressly granted.

\section{REFERENCES}

1 Clarke P, Wadhawan R, Smyth J, et al. Parenteral nutrition solution retrieved by lumbar puncture following left saphenous vein catheterization. J Paediatr Child Health 2003:39:386-9.

2 Payne R, Sieg EP, Choudhary A, et al. Pneumorrhachis Resulting in Transient Paresis after PICC Line Insertion into the Ascending Lumbar Vein. Cureus 2016;8:e833.

3 Ramasethu J. Complications of vascular catheters in the neonatal intensive care unit. Clin Perinatol 2008;35:199-222.

Copyright 2018 BMJ Publishing Group. All rights reserved. For permission to reuse any of this content visit http://group.bmj.com/group/rights-licensing/permissions.

BMJ Case Report Fellows may re-use this article for personal use and teaching without any further permission.

Become a Fellow of BMJ Case Reports today and you can:

- Submit as many cases as you like

- Enjoy fast sympathetic peer review and rapid publication of accepted articles

- Access all the published articles

Re-use any of the published material for personal use and teaching without further permission

For information on Institutional Fellowships contact consortiasales@bmjgroup.com

Visit casereports.bmj.com for more articles like this and to become a Fellow 